\section{Differentiation of Hydrogen Clays and Identification of their Mineral Con- stituents by Electrochemical and Viscous Methods}

A NUMBER of publications ${ }^{1,2,3,4}$ from this Laboratory have dealt with the acid character of hydrogen clays isolated from Indian soils as revealed from a study of their titration curves with bases, buffer indices and base-exchange capacities calculated at the inflexion points of the titration curves. An 'electrochemical method' for differentiating hydrogen clays and identifying clay minerals contained in them has been developed, based on a comparison of their electrochemical properties with those of hydrogen colloids isolated from natural deposits of the clay minerals. Hydrogen kaolinites (prepared by repeatedly leaching entire clay fractions with $0 \cdot 04 N$ hydrochloric acid and washing free from chlorides) from four different samples of kaolin and a number of hydrogen clays known, from $\mathrm{X}$-ray and dehydration studies carried out by Mr. S. N. Bagchi, to contain kaolinitic minerals have a dibasic acid character within the range of $p H$ $4-11 \cdot 0^{5,6}$. The first inflexion usually occurs between $p \mathrm{H} 7.0$ and 8.0 and the second between $p H$ 8.0 and 9.5 (see diagram). The ratio of the base-exchange capacities at the two inflexion points is nearly $2 \cdot 0$, though the actual value of the base-exchange capacity varies in the case of different hydrogen clays and hydrogen kaolinites from 12.0 m.e. to 23.0 m.e. per $100 \mathrm{gm}$. at the first inflexion point; and from 20.0 to $45.0 \mathrm{~m} . \Theta$. per $100 \mathrm{gm}$. at the second inflexion.

Hydrogen clays containing only montmorillonitic minerals as judged from $\mathrm{X}$-ray analysis show only one inflexion between $p H \mathbf{H} 7$ and 8.8 in their titration curve with caustic soda (see graph) and between $p H 5 \cdot 2$ and $7 \cdot 5$ when titrated with barium hydroxide and calcium hydroxide ${ }^{7,8}$. The base-exchange capacity calculated at this inflexion point varies from $55 \mathrm{~m} . \Theta$. to $100 \mathrm{~m} . e$. per $100 \mathrm{gm}$. for entire hydrogen clay fractions.

Another criterion for differentiating kaolinitic clays from those containing montmorillonitic minerals has been found and is based on the effect of addition of

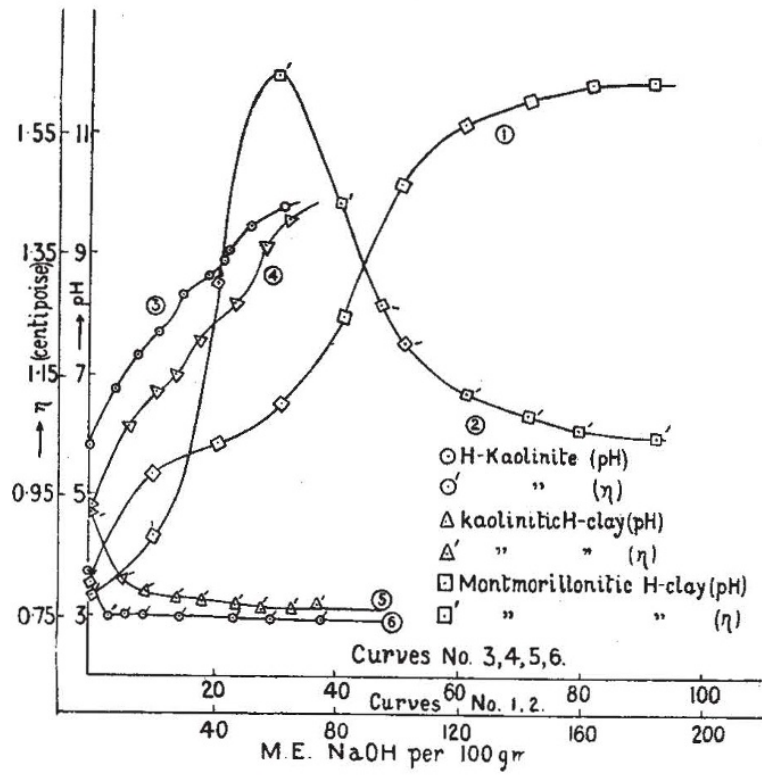

caustic soda on the viscosity of aqueous suspensions of the hydrogen clays. On the gradual addition of the alkali to hydrosols of hydrogen bentonites ${ }^{9}$ and montmorillonitic hydrogen clays ${ }^{10}$, their viscosity increases and passes through a maximum value at a point corresponding to about 75 per cent neutraliza. tion of the amount of the acid given by the inflexion point of the titration curve. Apart from a slight initial decrease, the alkali has no marked effect on the viscosity of hydrogen kaolinite and hydrogen clays containing only kaolinitic minerals within the range $p H$ 4-1l. The viscosity of one of the hydrogen kaolinites, $D$, slightly increased on the addition of the alkali, after which the viscosity remained practically constant. X-ray analysis showed that it contains montmorillonite in addition to kaolinitic minerals. Six subfractions having average equivalent spherical diameters $1 \cdot 4,0 \cdot 70$, $0.50,0.32,0.21$ and less than 0.18 microns were isolated by the graded centrifugalization of $D$. A concentration of montmorillonite in the finer sub. fractions was indicated by the chemical compositions; nature of potentiometric titration curves with caustic soda; base-exchange capacities; and the effect of the alkali on the viscosity.

J. N. MukherJeE.

R. P. Mitra.

Physical Chemistry Laboratory,

University College of Science and Technology, 92 Upper Circular Road, Calcutta.

${ }^{1}$ Mukherjee, Mitra and Mukherjee, Trans. Nat. Inst. Sci. India, 1, No. 10, 227 (1937).

'Mitra, Ind. J. Agric. Sci., 10, 317 (1940).

'Mukherjee and Mitra, Ind. J. Agric. Sci., 12, 433 (1942).

- Mitra, Bull. Ind. Soc. Soil Sci., No. 4, 41 (1942).

'Mukherjee, Mitra and Mitra, J. Phys. Chem., 47, 543 (1943).

- Mitra and Biswas, Proc. 31st Ind. Sci. Cong., 3, 152 (1944).

${ }^{7}$ Mitra, Bagehi and Ray, J. Phys. Chem., 47, 549 (1943).

${ }^{8}$ Mitra, Bagchi, Ray and Mukherjee, S., Ind. J. Agric. Sci., 13, 18 (1943).

- Mukherjce, Sen Gupta and Indra, J. Phys. Chem., 47, 553 (1943).

${ }^{10}$ Mitra, Indra and Ray, Proc. 31st Ind. Sei. Cong., 3, 152 (1944).

\section{Antioxidants and Prevention of Rancidity in certain Pacific Coast Fish}

DURING recent years it has been established that herring muscle ${ }^{1}$ and pork muscle ${ }^{2}$ possess a lipoxidase enzyme (or enzymes) which is capable of accelerating post-mortem oxidation of the tissue fats. This enzyme catalyses the formation of peroxides from the unsaturated fatty acids present, and consequently facilitates the development of rancid odours and flavours in the flesh. The enzyme concerned is sensitive to heat, will function actively at temperatures well below $0^{\circ} \mathrm{C}$. and its action is markedly accelerated by pure sodium chloride. This last-named property has been used to explain the fact that certain cured fish and meats are particularly liable to become rancid during storage.

On the north Pacific coast of America the flesh of many of the most valuable food fishes is rich in fat, and consequently cold storage of such fish under conditions which will prevent the formation of rancid fat has always presented a problem. The practice of lightly brining fillets prior to freezing them in order to prevent drip when they are thawed is by no means uncommon on this continent ${ }^{3}$, and this procedure is well known to lead to the premature development of a 'salt fish' flavour and rancidity in treated fillets. 